\title{
EFFECT OF HUMIC ACID COMBINED WITH FERTILIZER ON THE IMPROVEMENT OF SALINE-ALKALI LAND AND COTTON GROWTH
}

\author{
HU, Y. W. ${ }^{1,2}-$ LI, Q. K. ${ }^{* 1,2}-$ SONG, C. J. ${ }^{1,2}-$ JIN, X. H. ${ }^{1,2}$ \\ ${ }^{I}$ Yellow River Institute of Hydraulic Research, Zhengzhou, China \\ ${ }^{2}$ Key Laboratory of the Loess Plateau Soil Erosion and Water Loss Process and Control, \\ Zhengzhou, China \\ *Corresponding author \\ e-mail: luckdog3699@163.com
}

(Received $26^{\text {th }}$ Oct 2020; accepted $21^{\text {st }}$ Dec 2020)

\begin{abstract}
The effect of humic acid combined with fertilizer is an important basis for improving the soil's ecological environment. Therefore, this study is aimed at investigating the effect of the combined application of humic acid and fertilizer on the physicochemical properties of saline-alkali soil, cotton growth, and nutrient utilization in an arid area. The random field block test method was adopted, and biochemical humic acid (BHA), ammoniated humic acid (AHA), and microbial activated humic acid (MHA) were used as experimental materials. Soil $\mathrm{pH}$, electrical conductivity (EC), water-soluble cation content, soluble nitrogen content, available phosphorus content, cotton biomass, and yield were determined. The results showed that humic acid combined with fertilizer had no obvious effect on the $\mathrm{pH}$ of the salinized soil. However, the addition of three types of humic acid showed a certain reduction effect on soil EC, water-soluble $\mathrm{Na}^{+}$and $\mathrm{K}^{+}$content, and sodium adsorption ratio (SAR), affecting the soil depth of $0-40 \mathrm{~cm}$. In addition, the content of available phosphorus in soil could be increased by adding three humic acids, among which MHA was the best. The addition of humic acid could significantly improve the yield of cotton, but there was no significant difference between the three.
\end{abstract}

Keywords: biochemical humic acid, ammoniated humic acid, microbial activated humic acid, soil fertility, cotton yield

\section{Introduction}

Cotton cultivation in Xinjiang plays an important role in China's cotton production (Yang et al., 2019). In 2019, the area sown with cotton in Xinjiang was 2540.5 thousand hectares, and its total cotton output was 5.889 million tons, accounting for $76.1 \%$ and $84.9 \%$ of the national total, respectively ( $\mathrm{Li}$ et al., 2020). Due to scarce rainfall and intense evaporation, $37.72 \%$ of cultivated land in Xinjiang is endangered by salinealkali conditions (Xiao et al., 2019). Excessive salt ions and alkaline environment in saline-alkali soil cause the loss of nitrogen fertilizer volatilization, leading to cotton nutritional disorders, and thus affecting the growth and yield of cotton (He et al., 2020). Therefore, the fertilization of cotton in saline-alkali land should be determined not only based on the nutrient demand of cotton, but also the amelioration of saline-alkali land and the improvement of soil fertility.

Humic acid is a kind of organic polymer active material, which has been widely used in many fields (Ciarkowska et al., 2017; Dehghani et al., 2018; Xie et al., 2019). Studies have shown that humic acid itself can be used as an organic fertilizer to increase soil fertility (Zhang et al., 2019a). Fawzy et al. (2010) found that increasing humic acid application could improve the vegetative growth of bean plants and improve the yield and quality of beans. Fan et al. (2014) pointed out that the chlorophyll content and 
chloroplast ultrastructure of chrysanthemum were significantly improved after applying humic acid on the leaves compared with that after applying common chemical fertilizer. Selladurai and Purakayastha (2016) found that there was no significant difference between humic acid and fertilizer in yield, N, P, K content, absorption, and utilization efficiency. Li et al. (2019) showed that humic acid increased soil nutrient content, including total nitrogen, total phosphorus, total potassium, available nitrogen, available phosphorus, available potassium, and organic matter, showing the greatest effect in the third year. As a soil conditioner, humic acid can also change the composition of soil ions (Abe et al., 2011), promote the formation of soil aggregates (Liu et al., 2019), increase soil permeability (Khaled and Fawy, 2011), and accelerate the leaching and irrigation of soil surface salts and alkalis (Zhao et al., 2017). Humic acid can also activate soil phosphorus, improve the supply of phosphorus in saline-alkali soil, and promote the absorption and utilization of phosphorus by crops (He et al., 2011; Ifansyah, 2014). In addition, humic acid can regulate root morphogenesis and promote osmotic regulation of substance accumulation and nutrient absorption of crops (Asli and Neumann, 2010; Jindo et al., 2012).

The above studies indicate that humic acid plays a positive role in ameliorating saline-alkali soil and improving nutrient utilization efficiency. However, at present, the sources of humic acid are complex, and different sources of humic acid have great differences in chemical composition, structure, and properties, and their improvement effects on different types of saline-alkali soil are not the same (Erhayem and Sohn, 2014; Türkmen et al., 2004). The effects of different humic acids and chemical fertilizers on the improvement of saline-alkali land and crop growth are less studied. Therefore, 3 kinds of humic acids from different sources were used as the material in this study. Through field experiments, the effects of humic acids combined with fertilizers on soil physicochemical properties, cotton growth, and nutrient utilization in Xinjiang saline-alkali land were discussed, so as to clarify the application effects of different humic acids combined with fertilizers in saline-alkali land in inland arid areas.

\section{Materials and methods}

\section{The study area and test materials}

The experiment was conducted in Baotouhu Farm $\left(41^{\circ} 39^{\prime} \mathrm{N}, 85^{\circ} 48^{\prime} \mathrm{E}\right)$ in Korla, Xinjiang, China in 2016. This region is a typical inland arid climate type, with annual precipitation of 53.5-62.5 mm, evaporation of $2270-2785 \mathrm{~mm}$, average temperature of $11.2^{\circ} \mathrm{C}$, annual sunshine number of $3035.7 \mathrm{~h}$, wind speed of $2.36 \mathrm{~m} \cdot \mathrm{s}^{-1}$, and frost-free period of 145-242 days. Before the experiment, the physical and chemical properties of the initial soil were determined. The soil in the study area $(0-40 \mathrm{~cm})$ was sandy loam ( $64.27 \%$ sand, $32.83 \%$ silt, $2.9 \%$ clay), soil bulk density was $1.70 \mathrm{~g} \cdot \mathrm{cm}^{-3}$, saturated water content was $0.398 \mathrm{~cm}^{3} \mathrm{~cm}^{-3}$, wilting coefficient was $0.050 \mathrm{~cm}^{3} \cdot \mathrm{cm}^{-3}$, field water capacity was $0.196 \mathrm{~cm}^{3} \cdot \mathrm{cm}^{-3}$, organic matter content was $10.7 \mathrm{~g} \mathrm{~kg}^{-1}$, total nitrogen was $0.61 \mathrm{~g} \cdot \mathrm{kg}^{-}$ 1 , available phosphorus was $18.64 \mathrm{mg} \cdot \mathrm{kg}^{-1}$, available potassium was $233 \mathrm{mg} \cdot \mathrm{kg}^{-1}, \mathrm{pH}$ was 8.27 , and electroconductibility (EC) was $5.47 \mathrm{ds} \cdot \mathrm{m}^{-1}$. The tested cotton variety was No. 43 of Zhonglu Institute. The tested fertilizer urea $(\mathrm{N}, 46.4 \%)$ and superphosphate $\left(\mathrm{P}_{2} \mathrm{O}_{5}\right.$, $14 \%$ ) was purchased from the market. The 3 humic acids were all provided by Beijing Aojia Ecological Agriculture Co., LTD., including biochemical humic acid (BHA), ammoniated humic acid (AHA), and microbial activated humic acid (MHA). The basic physicochemical properties of the 3 humic acids are shown in Table 1. 
Table 1. Basic physicochemical properties of humic acid material

\begin{tabular}{|c|c|c|c|c|c|c|}
\hline $\begin{array}{c}\text { Tested } \\
\text { material }\end{array}$ & $\begin{array}{c}\text { Organic } \\
\text { matter }(\%)\end{array}$ & $\begin{array}{c}\text { Humic acid } \\
(\%)\end{array}$ & $\begin{array}{c}\text { Total nitrogen } \\
\left(\mathrm{g}^{\prime} \cdot \mathrm{kg}^{-1}\right)\end{array}$ & $\begin{array}{c}\text { Total phosphorus } \\
\left(\mathrm{g}^{\prime} \cdot \mathrm{kg}^{-1}\right)\end{array}$ & $\begin{array}{c}\text { Total potassium } \\
\left(\mathrm{g}^{\mathrm{g}} \mathrm{kg}^{-1}\right)\end{array}$ & pH \\
\hline BHA & 70 & 40 & 1.8 & 11.8 & 19.8 & 9.72 \\
\hline AHA & 50 & 40 & 47.1 & 11.9 & 0.9 & 9.89 \\
\hline MHA & 50 & 40 & 25.1 & 16.2 & 2.2 & 8.35 \\
\hline
\end{tabular}

\section{Experimental design}

Using the field test method, 6 treatments were set as follows:

1. - $\mathrm{N}$ (only phosphorus fertilizer, no nitrogen fertilizer)

2. -P (only nitrogen fertilizer, no phosphorus fertilizer)

3. NP (nitrogen and phosphate fertilizer)

4. $\mathrm{BHA}+\mathrm{NP}$ (BHA combined with nitrogen and phosphate fertilizer)

5. AHA + NP (AHA combined with nitrogen and phosphorus fertilizer)

6. MHA + NP (MHA combined with nitrogen and phosphate fertilizer)

Each treatment area was $30 \mathrm{~m}^{2}$ (6 $\mathrm{m}$ long and $5 \mathrm{~m}$ wide), with 3 replicates, arranged in random groups. A one-time application of urea $\left(420 \mathrm{~kg} \cdot \mathrm{hm}^{-2}\right)$ and superphosphate $\left(643 \mathrm{~kg} \cdot \mathrm{hm}^{-2}\right)$ was as base fertilizer, and three humic acids were applied at $1500 \mathrm{~kg} \cdot \mathrm{hm}^{-2}$. Considering the high content of available potassium in the test soil, potassium fertilizer was not applied in the field.

Cotton was planted by drip irrigation under the film. The experimental field was sown on April 20, 2016, with a film and two pipes arranged in four rows. The plant spacing was $10 \mathrm{~cm}$, the narrow row spacing was $20 \mathrm{~cm}$, the wide row spacing was $50 \mathrm{~cm}$, and the film spacing was $40 \mathrm{~cm}$. The prevention and control of diseases, pests, and weeds during cotton growth and water management were equivalent to conventional production fields. The irrigation quota of cotton growth period was $5250 \mathrm{~m}^{3} \cdot \mathrm{hm}^{-2}$, the irrigation period was 7-10 days, and the total irrigation time was 10 times. Aphids and red spiders were prevented at stage 14 in $\mathrm{BBCH}$ scale and cotton bollworms were prevented at stage 61 in $\mathrm{BBCH}$ scale for cotton.

\section{Investigate items and methods}

The chlorophyll content of functional leaves was measured by SPAD-50-Puls portable chlorophyll meter at stages 56 and 75 in $\mathrm{BBCH}$ scale for cotton. At stage 105 in $\mathrm{BBCH}$ scale, three uniformly robust fields with an area of $6.67 \mathrm{~m}^{2}$ were selected, the number of bolls with a diameter greater than $2 \mathrm{~cm}$ were recorded, 100 bolls were selected to be weighed in each test area, so as to calculate the cotton yield (Liang et al., 2019). Four plants of cotton were taken in each experimental plot, and the root, stem, leaf, and bell were determined by the drying method (Tan et al., 2018). The dried cotton plants were crushed for the determination of nitrogen and phosphorus content. The plant samples were digested with concentrated $\mathrm{H}_{2} \mathrm{SO}_{4}-\mathrm{H}_{2} \mathrm{O}_{2}$, total nitrogen was determined by the Kjeldahl method, and total phosphorus was determined by the vanadiummolybdenum yellow colorimetric method (Sudiarto et al., 2019). Soil samples (100 g, three replicates) were taken from soil layers of $0-10 \mathrm{~cm}, 10-20 \mathrm{~cm}$, and $20-40 \mathrm{~cm}$ respectively to determine the contents of $\mathrm{pH}, \mathrm{EC}$, the contents of water-soluble $\mathrm{K}^{+}, \mathrm{Na}^{+}$, 
$\mathrm{Ca}^{2+}$, and $\mathrm{Mg}^{2+}, \mathrm{NO}_{3}{ }^{-}-\mathrm{N}, \mathrm{NH}_{4}{ }^{+}-\mathrm{N}$, and soluble total nitrogen (TSN) as well as available phosphorus. Soil $\mathrm{pH}$ was determined by $\mathrm{pH}$ meter method, soil electroconductibility (EC) was determined by electroconductibility meter method, water-soluble $\mathrm{Ca}^{2+}$ and $\mathrm{Mg}^{2+}$ were determined by atomic absorption spectrophotometry method, and watersoluble $\mathrm{K}^{+}$and $\mathrm{Na}^{+}$were determined by flame photometry method (Sharpley, 1991). $\mathrm{NO}_{3}{ }^{-}-\mathrm{N}$ was determined by UV spectrophotometer method, $\mathrm{NH}_{4}{ }^{+}-\mathrm{N}$ by indophenol blue colorimetric method, and TSN by alkaline potassium persulfate oxidation method (Margot et al., 1994). The content of available phosphorus in soil was determined by $0.5 \mathrm{~mol} \cdot \mathrm{L}^{-1} \mathrm{NaHCO}_{3}$ extraction and molybdenum-antimony resistance colorimetric method (Zhang et al., 2019b).

\section{Data processing and analysis}

Microsoft Excel 2016 and SPSS 22.0 statistical software were used for data processing and statistical analysis, and the least significant difference (LSD) method $(\alpha=0.05)$ was used for multiple comparison.

Xing et al. (2010) proposed the calculation method of soil soluble organic nitrogen $(\mathrm{SON})$ :

$$
\mathrm{SON}=\mathrm{TSN}-\left(\mathrm{NH}_{4}^{+}-\mathrm{N}+\mathrm{NO}_{3}^{-}-\mathrm{N}\right)
$$

where TSN is soil soluble total nitrogen.

Mahdy (2011) used the calculation formula of soil sodium adsorption ratio (SAR):

$$
\mathrm{SAR}=\frac{\left[\mathrm{Na}^{+}\right]}{\sqrt{\frac{\left[\mathrm{Ca}^{2+}\right]+\left[\mathrm{Mg}^{2+}\right]}{2}}}
$$

Zhang et al. (2016) and Wang et al. (2019) proposed the calculation method of apparent availability of nitrogen (phosphorus) fertilizer, nitrogen (phosphorus) agronomic efficiency, and nitrogen (phosphorus) partial productivity.

$$
\begin{gathered}
\mathrm{AAN}=\frac{\mathrm{NUF}-\mathrm{NUD}}{\mathrm{NUA}} \times 100 \% \\
\mathrm{AAP}=\frac{\mathrm{PUF}-\mathrm{PUD}}{\mathrm{PUA}} \times 100 \% \\
\mathrm{NAE}=\frac{\mathrm{Y}_{\mathrm{F}}-\mathrm{Y}_{\mathrm{DN}}}{\mathrm{NUA}} \\
\mathrm{PAE}=\frac{\mathrm{Y}_{\mathrm{F}}-\mathrm{Y}_{\mathrm{DP}}}{\mathrm{PUA}} \\
\mathrm{NPP}=\frac{\mathrm{Y}_{\mathrm{F}}}{\mathrm{NUA}}
\end{gathered}
$$




$$
\mathrm{PPP}=\frac{\mathrm{Y}_{\mathrm{F}}}{\mathrm{PUA}}
$$

where AAN and AAP represent the apparent availability of nitrogen (phosphorus) fertilizer (\%), NUF and PUF represent the amounts of nitrogen (phosphorus) uptake in the fertilized area (kg), NUD and PUD represent the amounts of nitrogen (phosphorus) uptake in nitrogen (phosphorus) deficient area $(\mathrm{kg})$, and NUA and PUA represent the amounts of nitrogen (phosphorus) nutrient application $(\mathrm{kg})$. NAE and PAE represent nitrogen (phosphorus) agronomic efficiency $\left(\mathrm{kg} \cdot \mathrm{kg}^{-1}\right), \mathrm{Y}_{\mathrm{F}}$ represents fertilized area yield, $Y_{D N}$ and $Y_{D P}$ represent nitrogen (phosphorus) deficient area yields. NPP and PPP represent nitrogen (phosphorus) partial productivity $\left(\mathrm{kg} \cdot \mathrm{kg}^{-1}\right)$.

\section{Results}

\section{The effect of humic acid combined with fertilizer on soil pH}

The $\mathrm{pH}$ value directly affects many chemical reactions in the soil. In $0-40 \mathrm{~cm}$ soil layer, $\mathrm{pH}$ value showed a trend of gradual increase with soil depth (Fig. 1). Compared with the control group (NP) without humic acid, the application of 3 kinds of humic acid materials had no significant effect on the $\mathrm{pH}$ value of the soil at $0-10 \mathrm{~cm}, 10$ $20 \mathrm{~cm}$, and 20-40 cm soil layers. However, compared with the three humic acid materials, the $\mathrm{pH}$ value of the soil treated with BHA in the $0-10 \mathrm{~cm}$ soil layer was lower than that of AHA and MHA (Fig.1A), the $\mathrm{pH}$ value of the soil treated with MHA in the 10-20 cm soil layer was lower than that of AHA (Fig.1B), and there was no significant difference between the three test materials in the $20-40 \mathrm{~cm}$ soil layer (Fig. 1C).
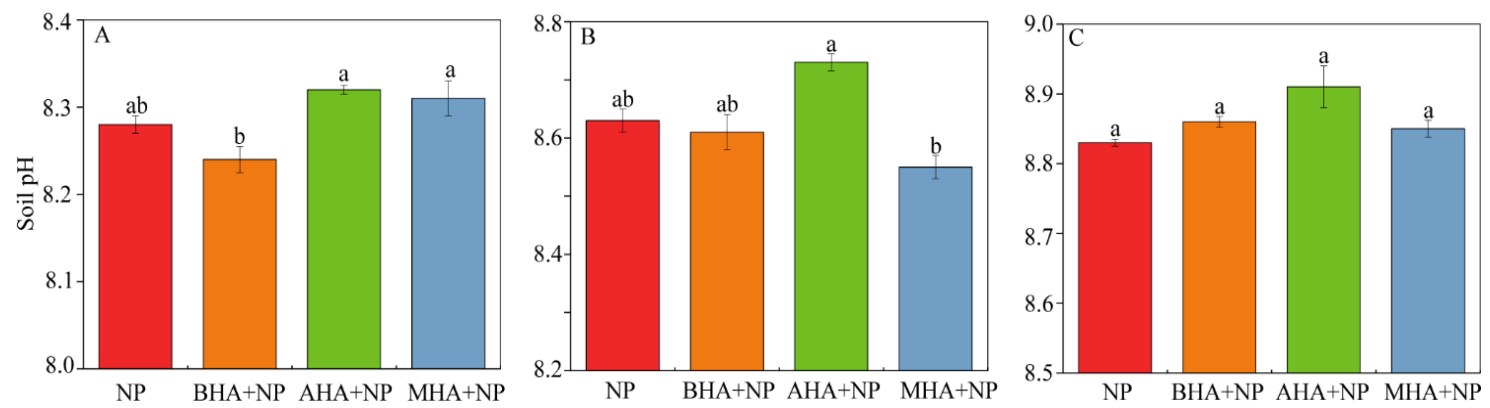

Figure 1. Influence of humic acid combined with fertilizer on soil $\mathrm{pH}$. A, B, and C represent soil layers 0-10 cm, 10-20 cm, and 20-40 cm, respectively. "NP" represents nitrogen and phosphate fertilizer, "BHA $+N P$ " represents biochemical humic acid combined with nitrogen and phosphate fertilizer, "AHA $+N P$ " represents ammoniated humic acid combined with nitrogen

and phosphorus fertilizer), and "MHA + NP" represents microbial activated humic acid

combined with nitrogen and phosphate fertilizer. The error lines represent the standard variance, and different lowercase letters represent significant differences among treatments in the same soil layer $(P<0.05)$

\section{The effect of humic acid combined with fertilizer on soil electric conductivity}

As a saline-alkali soil improvement agent, humic acid had a certain effect on electroconductibility (EC) of 0-40 cm soil layer (Fig. 2). Compared with control (NP), the EC values of $0-10 \mathrm{~cm}$ soil layer treated by BHA, AHA and MHA decreased by 
$27.4 \%, 26.3 \%$, and $21.4 \%$ respectively (Fig. $2 A$ ), the EC values of 10-20 soil layer decreased by $23.8 \%, 21.9 \%$, and $12.7 \%$ respectively (Fig. $2 B$ ), and the EC values of 20 $40 \mathrm{~cm}$ soil layer decreased by $20.9 \%, 131 \%$, and $8.8 \%$ respectively (Fig. 2C). Compared with NP, BHA in the three soil layers all showed significant differences, while AHA and MAH only showed significant differences in the $0-10 \mathrm{~cm}$ soil layer.
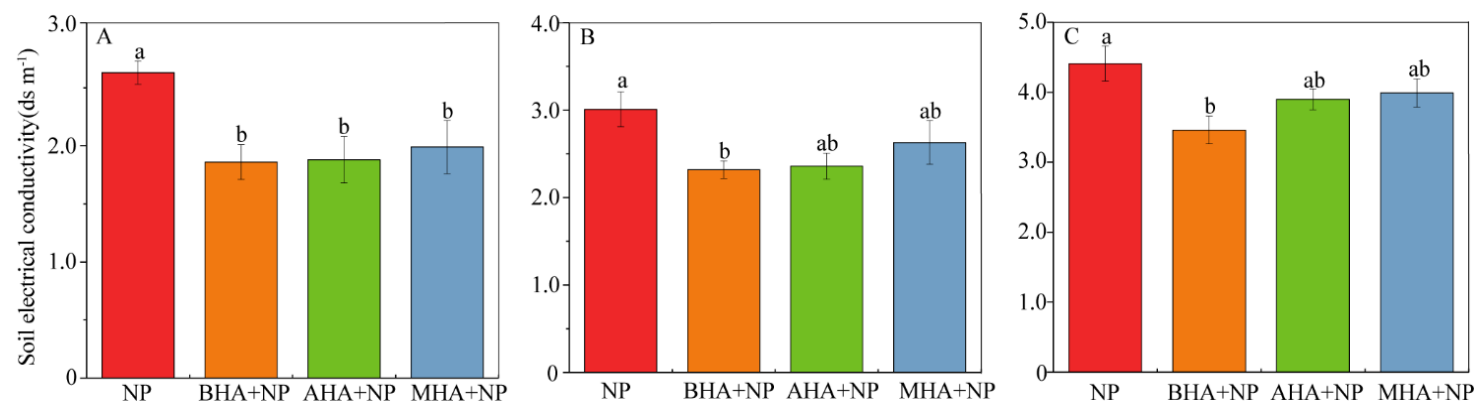

Figure 2. Influence of humic acid combined with fertilizer on soil electric conductivity. $A, B$, and $C$ represent soil layers $0-10 \mathrm{~cm}, 10-20 \mathrm{~cm}$, and $20-40 \mathrm{~cm}$, respectively. "NP" represents nitrogen and phosphate fertilizer, "BHA +NP" represents biochemical humic acid combined with nitrogen and phosphate fertilizer, "AHA +NP" represents ammoniated humic acid combined with nitrogen and phosphorus fertilizer), and "MHA +NP" represents microbial activated humic acid combined with nitrogen and phosphate fertilizer. The error lines represent the standard variance, and different lowercase letters represent significant differences among treatments in the same soil layer $(P<0.05)$

\section{The effect of humic acid combined with fertilizer on soil cation composition and SAR}

Soil salinization is the process of adsorption of sodium ions by soil colloid and the exchange of cations between the solid phase and liquid phase, and sodium adsorption ratio (SAR) is an important indicator of soil alkalinization. Compared with NP, the combination of humic acid and fertilizer had no significant effect on the content of water-soluble $\mathrm{Ca}^{2+}$ and $\mathrm{Mg}^{2+}$ in the $0-40 \mathrm{~cm}$ soil layer, but reduced the content of watersoluble $\mathrm{K}^{+}$and $\mathrm{Na}^{+}$by $5.5-40.0 \%$ and $12.8-22.0 \%$, respectively. Among the three humic acid materials, the content of water-soluble $\mathrm{Ca}^{2+}$ and $\mathrm{Mg}^{2+}$ in the $0-10 \mathrm{~cm}$ soil layer treated by MHA was significantly higher than that of BHA and AHA, and there was no significant difference in the soil layer below $10 \mathrm{~cm}$. The content of water-soluble $\mathrm{K}^{+}$in the $20-40 \mathrm{~cm}$ soil layer treated by AHA was significantly higher than that of BHA and MHA. However, there was no significant difference in the content of water-soluble $\mathrm{Na}^{+}$ among the three materials in any soil layer. The combination of three humic acids and fertilizers can significantly reduce the SAR of $0-40 \mathrm{~cm}$ soil layer by $7.7-22.7 \%$. However, there was no significant difference between different humic acid materials (Table 2).

\section{The effect of humic acid combined with fertilizer on soil soluble nitrogen content}

Soil inorganic nitrogen mainly includes nitrate nitrogen $\left(\mathrm{NO}_{3}^{-}-\mathrm{N}\right)$ and ammonium nitrogen $\left(\mathrm{NH}_{4}{ }^{+}-\mathrm{N}\right)$. Compared with $\mathrm{NP}$, the content of $\mathrm{NO}_{3}{ }^{-} \mathrm{N}$ in the $0-40 \mathrm{~cm}$ soil layer at the maturity stage of cotton treated with BHA, AHA and MHA decreased by 9.9$28.1 \%, 18.0-78.6 \%$ and 37.6-66.2\%, respectively, especially the AHA and MHA humic acid treatment showed the greatest reduction (Table 3). The influence of $\mathrm{NH} 4+-\mathrm{N}$ 
content in soil treated with MHA was not significant, but the $\mathrm{NH}_{4}{ }^{+}-\mathrm{N}$ content in soil treated with MHA was significantly increased in $0-10 \mathrm{~cm}$ and $20-40 \mathrm{~cm}$ soil layers (Table 3).

Table 2. Effects of humic acid combined with fertilizer on soil water-soluble cation composition and SAR

\begin{tabular}{c|c|c|c|c|c|c}
\hline \multirow{2}{*}{ Soil layer (cm) } & \multirow{2}{*}{ Treatment } & \multicolumn{4}{|c|}{ Cation content $\left(\mathbf{c m o l \cdot k g ^ { - 1 } )}\right.$} & \multirow{2}{*}{ SAR } \\
\cline { 3 - 6 } & & $\mathbf{K}^{+}$ & $\mathbf{N a}^{+}$ & $\mathbf{C a}^{\mathbf{2}}$ & $\mathbf{M g}^{\mathbf{2 +}}$ & \\
\hline \multirow{3}{*}{$0-10$} & $\mathrm{NP}$ & $6.16 \mathrm{a}$ & $20.86 \mathrm{a}$ & $4.9 \mathrm{ab}$ & $1.68 \mathrm{ab}$ & $11.5 \mathrm{a}$ \\
& BHA + NP & $5.60 \mathrm{ab}$ & $18.20 \mathrm{~b}$ & $4.34 \mathrm{~b}$ & $1.54 \mathrm{~b}$ & $10.61 \mathrm{~b}$ \\
& AHA + NP & $5.18 \mathrm{~b}$ & $16.80 \mathrm{~b}$ & $4.20 \mathrm{~b}$ & $1.40 \mathrm{~b}$ & $10.04 \mathrm{~b}$ \\
& MHA + NP & $4.90 \mathrm{~b}$ & $16.80 \mathrm{~b}$ & $5.32 \mathrm{a}$ & $1.82 \mathrm{a}$ & $8.89 \mathrm{~b}$ \\
\hline \multirow{3}{*}{$10-20$} & NP & $4.90 \mathrm{a}$ & $45.50 \mathrm{a}$ & $5.04 \mathrm{a}$ & $1.96 \mathrm{a}$ & $24.32 \mathrm{a}$ \\
& BHA + NP & $2.94 \mathrm{~b}$ & $38.92 \mathrm{~b}$ & $4.76 \mathrm{a}$ & $1.96 \mathrm{a}$ & $21.23 \mathrm{~b}$ \\
& AHA + NP & $3.78 \mathrm{~b}$ & $37.66 \mathrm{~b}$ & $4.62 \mathrm{a}$ & $2.10 \mathrm{a}$ & $20.54 \mathrm{~b}$ \\
& MHA + NP & $4.06 \mathrm{~b}$ & $38.36 \mathrm{~b}$ & $4.76 \mathrm{a}$ & $1.96 \mathrm{a}$ & $20.93 \mathrm{~b}$ \\
\hline \multirow{5}{*}{$20-40$} & NP & $3.64 \mathrm{a}$ & $61.18 \mathrm{a}$ & $6.44 \mathrm{a}$ & $2.10 \mathrm{a}$ & $29.61 \mathrm{a}$ \\
& BHA + NP & $3.08 \mathrm{~b}$ & $52.64 \mathrm{~b}$ & $6.02 \mathrm{a}$ & $2.24 \mathrm{a}$ & $25.90 \mathrm{~b}$ \\
& AHA + NP & $3.44 \mathrm{a}$ & $53.20 \mathrm{~b}$ & $6.16 \mathrm{a}$ & $2.52 \mathrm{a}$ & $25.54 \mathrm{~b}$ \\
& MHA + NP & $3.08 \mathrm{~b}$ & $47.74 \mathrm{~b}$ & $6.30 \mathrm{a}$ & $2.38 \mathrm{a}$ & $22.92 \mathrm{~b}$ \\
\hline
\end{tabular}

"NP" represents nitrogen and phosphate fertilizer, "BHA + NP" represents biochemical humic acid combined with nitrogen and phosphate fertilizer, "AHA + NP" represents ammoniated humic acid combined with nitrogen and phosphorus fertilizer), and "MHA + NP" represents microbial activated humic acid combined with nitrogen and phosphate fertilizer. Different lowercase letters represent significant differences among treatments in the same soil layer $(P<0.05)$

Table 3. Effects of humic acid combined with fertilizer on soil soluble nitrogen content $\left(m g \cdot k g^{-1}\right)$

\begin{tabular}{c|c|c|c|c|c}
\hline Soil layer (cm) & Treatment & NH $^{+}-\mathbf{N}$ & NO $^{-}-\mathbf{N}$ & SON & TSN \\
\hline \multirow{5}{*}{$0-10$} & NP & $1.68 \mathrm{~b}$ & $7.52 \mathrm{a}$ & $9.03 \mathrm{~b}$ & $17.42 \mathrm{~b}$ \\
& BHA + NP & $2.24 \mathrm{ab}$ & $6.76 \mathrm{ab}$ & $10.18 \mathrm{~b}$ & $19.42 \mathrm{~b}$ \\
& AHA + NP & $2.03 \mathrm{ab}$ & $6.15 \mathrm{~b}$ & $14.54 \mathrm{a}$ & $22.89 \mathrm{a}$ \\
& MHA + NP & $2.41 \mathrm{a}$ & $4.68 \mathrm{c}$ & $14.70 \mathrm{a}$ & $22.33 \mathrm{a}$ \\
\hline \multirow{5}{*}{$10-20$} & NP & $1.79 \mathrm{ab}$ & $6.13 \mathrm{a}$ & $9.87 \mathrm{~b}$ & $18.72 \mathrm{a}$ \\
& BHA + NP & $1.41 \mathrm{~b}$ & $6.41 \mathrm{~b}$ & $11.68 \mathrm{a}$ & $18.89 \mathrm{a}$ \\
& AHA + NP & $2.08 \mathrm{a}$ & $1.83 \mathrm{c}$ & $7.45 \mathrm{~b}$ & $11.76 \mathrm{c}$ \\
& MHA + NP & $1.93 \mathrm{a}$ & $2.07 \mathrm{c}$ & $12.13 \mathrm{~b}$ & $14.73 \mathrm{~d}$ \\
\hline \multirow{5}{*}{$20-40$} & $\mathrm{NP}$ & $1.27 \mathrm{bc}$ & $13.14 \mathrm{a}$ & $7.44 \mathrm{~b}$ & $21.51 \mathrm{a}$ \\
& BHA + NP & $1.15 \mathrm{c}$ & $10.54 \mathrm{~b}$ & $9.63 \mathrm{a}$ & $21.58 \mathrm{a}$ \\
& AHA + NP & $1.57 \mathrm{~b}$ & $2.81 \mathrm{~d}$ & $6.98 \mathrm{~b}$ & $12.39 \mathrm{c}$ \\
& MHA + NP & $1.78 \mathrm{a}$ & $5.12 \mathrm{c}$ & $9.75 \mathrm{a}$ & $15.76 \mathrm{~d}$ \\
\hline
\end{tabular}

SON and TSN represent soil soluble organic nitrogen and soluble total nitrogen respectively. "NP" represents nitrogen and phosphate fertilizer, "BHA + NP" represents biochemical humic acid combined with nitrogen and phosphate fertilizer, "AHA + NP" represents ammoniated humic acid combined with nitrogen and phosphorus fertilizer), and "MHA + NP" represents microbial activated humic acid combined with nitrogen and phosphate fertilizer. Different lowercase letters represent significant differences among treatments in the same soil layer $(P<0.05)$ 
The analysis results of soluble organic nitrogen (SON) showed that the SON content in the $10-20 \mathrm{~cm}$ and $20-40 \mathrm{~cm}$ soil layers treated with BHA was significantly higher than NP content, while that in the $0-10 \mathrm{~cm}$ soil layer treated with AHA was significantly higher than NP content, and that in the $0-10 \mathrm{~cm}$ and $20-40 \mathrm{~cm}$ soil layers treated with MHA was significantly higher than NP content (Table 3). Thus, the application of humic acid has the effect of increasing SON content, and the depth of BHA and MHA in the season of application reaches $40 \mathrm{~cm}$ soil layer, while AHA only has a significant effect at $0-10 \mathrm{~cm}$ soil layer.

Soil soluble total nitrogen (TSN) is the sum of $\mathrm{NO}_{3}{ }^{-}-\mathrm{N}, \mathrm{NH}_{4}{ }^{+}-\mathrm{N}$, and SON. The TSN content of BHA and NP in the $0-40 \mathrm{~cm}$ soil layer was not significantly different, while the TSN content of AHA and MHA in the $0-10 \mathrm{~cm}$ soil layer was significantly higher than NP, and the TSN content of AHA and MHA in the $0-10 \mathrm{~cm}$ soil layer was significantly lower than NP. Among the three humic acids, BHA in $0-10 \mathrm{~cm}$ soil layer was lower than AHA and MHA, and there is no significant difference between the latter two. The TSN content in the $10-40 \mathrm{~cm}$ soil layer was manifested as BHA > MHA > AHA, and the difference between the three treatments was significant.

\section{The effect of humic acid combined with fertilizer on soil available phosphorus content}

The content of available phosphorus in $0-40 \mathrm{~cm}$ soil significantly decreased with the increase of soil depth (Fig. 3). The combination of humic acid and fertilizer significantly increased the available phosphorus content in soil layers $0-10 \mathrm{~cm}$ and 20 $40 \mathrm{~cm}$ by $17.9-73.4 \%$, and 62.3-98.4\%, respectively (Fig. $3 A$ and $C$ ), but the available phosphorus content in soil layers $10-20 \mathrm{~cm}$ showed no obvious advantage (Fig. 3B). The content of available phosphorus in soil under MHA treatment was the highest in all 3 soil layers and was significantly higher in $0-10 \mathrm{~cm}$ soil layer than other treatments.

\section{The effect of humic acid combined with fertilizer on chlorophyll content and biomass of cotton}

No application of nitrogen fertilizer or phosphorus fertilizer had no significant effect on the chlorophyll content of cotton functional leaves at the flowering and boll period, but it significantly reduced the total biomass of cotton. The combination of humic acid and fertilizer effectively increased the chlorophyll content of functional leaves by $6.7-8.4 \%$ compared with NP, but the difference between the three humic acid materials was not significant. In addition, the combined application of BHA, AHA, and MHA increased the total biomass of cotton by $9.2 \%, 19.3 \%$, and $11.6 \%$, respectively, compared with NP (Table 4). The analysis of biomass distribution of different parts of cotton plants showed that nitrogen deficiency mainly affected the biomass of leaves, stems, and bolls, phosphorus deficiency mainly affected the biomass of leaves and bolls, and humic acid combined with nitrogen and phosphorus mainly promoted the biomass of leaves and bolls.

\section{The effect of humic acid combined with fertilizer on yield and components of cotton}

Under the condition of soil fertility, only nitrogen or phosphorus fertilizer could significantly reduce cotton yield. Compared with the application of nitrogen and phosphorus fertilizer (NP), the yield of cotton increased by $15.9 \%, 15.9 \%$, and $14.1 \%$ respectively with the addition of BHA, AHA, and MHA. However, the yield of cotton among the three humic acid treatments was almost the same (Table 5). Through the analysis 
of the components of cotton yield, it was found that the deficiency of nitrogen supply in saline-alkali land had a significant effect on the number of effective bolls per plant and the weight of a single boll. The deficiency of phosphorus supply mainly affected the weight of single boll. The increase of cotton yield with BHA and AHA was mainly due to the increase of the number of effective bolls per plant, while the combination of MHA and chemical fertilizer had a significant effect on the weight of a single boll.
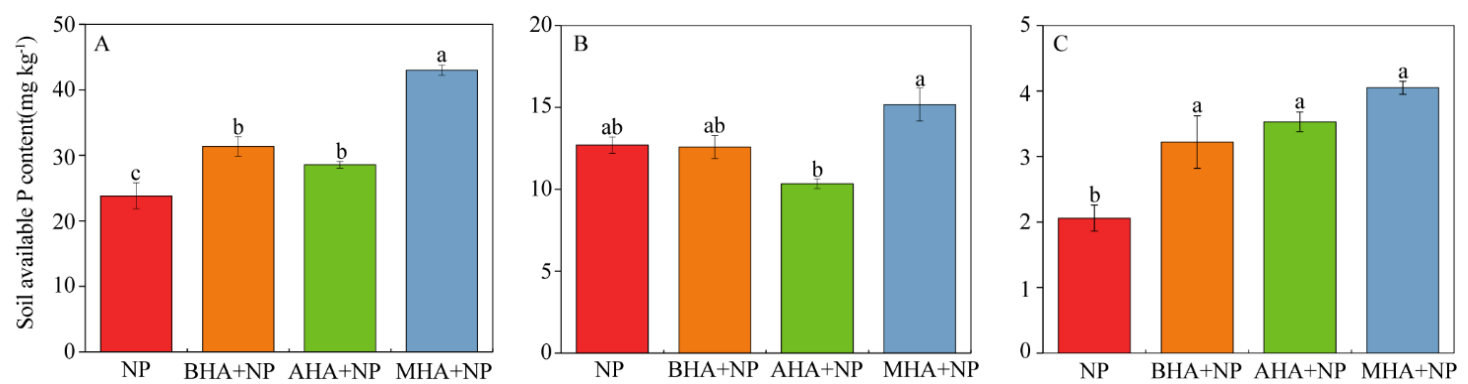

Figure 3. Influence of humic acid combined with fertilizer on soil available phosphorus content.

$A, B$ and $C$ represent soil layers $0-10 \mathrm{~cm}, 10-20 \mathrm{~cm}$ and $20-40 \mathrm{~cm}$, respectively. "NP" represents nitrogen and phosphate fertilizer, "BHA +NP" represents biochemical humic acid combined with nitrogen and phosphate fertilizer, "AHA +NP" represents ammoniated humic

acid combined with nitrogen and phosphorus fertilizer), and "MHA +NP" represents microbial activated humic acid combined with nitrogen and phosphate fertilizer. The error lines represent the standard variance, and different lowercase letters represent significant differences among treatments in the same soil layer $(P<0.05)$

Table 4. Effects of humic acid combined with fertilizer on chlorophyll content and biomass of cotton

\begin{tabular}{c|c|c|c|c|c|c}
\hline \multirow{2}{*}{ Treatment } & \multirow{2}{*}{ SPAD } & \multicolumn{5}{|c}{ Biomass $\left(\mathbf{t ~ h m}^{-2}\right)$} \\
\cline { 3 - 7 } & & Root & Stem & Leaf & boll & Total biomass \\
\hline$-\mathrm{N}$ & $54.75 \mathrm{~b}$ & $0.62 \mathrm{ab}$ & $3.91 \mathrm{c}$ & $7.21 \mathrm{c}$ & $14.29 \mathrm{~d}$ & $26.03 \mathrm{c}$ \\
$-\mathrm{P}$ & $56.84 \mathrm{ab}$ & $0.64 \mathrm{ab}$ & $4.46 \mathrm{~b}$ & $6.81 \mathrm{c}$ & $15.38 \mathrm{c}$ & $27.29 \mathrm{c}$ \\
$\mathrm{NP}$ & $55.65 \mathrm{~b}$ & $0.69 \mathrm{a}$ & $4.10 \mathrm{bc}$ & $8.41 \mathrm{~b}$ & $19.23 \mathrm{~b}$ & $32.43 \mathrm{~b}$ \\
BHA + NP & $60.34 \mathrm{a}$ & $0.71 \mathrm{a}$ & $4.23 \mathrm{~b}$ & $9.12 \mathrm{ab}$ & $21.35 \mathrm{a}$ & $35.41 \mathrm{ab}$ \\
AHA + NP & $59.76 \mathrm{a}$ & $0.59 \mathrm{~b}$ & $5.48 \mathrm{a}$ & $11.73 \mathrm{a}$ & $20.88 \mathrm{a}$ & $38.68 \mathrm{a}$ \\
MHA + NP & $59.39 \mathrm{a}$ & $0.69 \mathrm{a}$ & $4.40 \mathrm{~b}$ & $10.55 \mathrm{a}$ & $20.55 \mathrm{a}$ & $36.19 \mathrm{ab}$ \\
\hline
\end{tabular}

“-N" represents only phosphorus fertilizer, no nitrogen fertilizer, “-P” represents only nitrogen fertilizer, no phosphorus fertilizer, "NP" represents nitrogen and phosphate fertilizer, "BHA + NP" represents biochemical humic acid combined with nitrogen and phosphate fertilizer, "AHA + NP" represents ammoniated humic acid combined with nitrogen and phosphorus fertilizer), and "MHA + NP" represents microbial activated humic acid combined with nitrogen and phosphate fertilizer. Different lowercase letters represent significant differences among treatments in the same soil layer $(P<0.05)$

\section{The effect of humic acid combined with fertilizer on absorption and utilization of nitrogen and phosphorus in cotton}

The nitrogen and phosphorus utilization rates of cotton with combined application of humic acid and fertilizer increased by $42.0-105.8 \%$ and $52.7-112.7 \%$, respectively, with significant differences. Among the three tested humic acid materials, 
AHA > MHA > BHA (Table 6). Compared with NP, the agronomic efficiency of nitrogen and phosphorus increased by $29.6-51.9 \%$ and $47.2-71.7 \%$, respectively, after the combination of humic acid and fertilizer. The agronomic efficiency of BHA combined with fertilizer was the highest, which indicated that the application of BHA was more conducive to the improvement of unit nutrient yield. The partial productivity of nitrogen and phosphate fertilizer treated with humic acid was significantly higher than that of the control group, but there was no significant difference among the three humic acid materials.

Table 5. Effects of humic acid combined with fertilizer on yield and components of cotton

\begin{tabular}{c|c|c|c}
\hline \multirow{2}{*}{ Treatment } & \multicolumn{2}{|c|}{ Yield components } & \multirow{2}{*}{ Yield $\left(\mathbf{k g ~ h m}^{\mathbf{- 2}}\right)$} \\
\cline { 2 - 3 } & Effective bolls per plant & Single boll weight $(\mathbf{g})$ & \\
\hline$-\mathrm{N}$ & $5.87 \mathrm{~d}$ & $5.93 \mathrm{~d}$ & $4212 \mathrm{~d}$ \\
$-\mathrm{P}$ & $6.96 \mathrm{~cd}$ & $6.04 \mathrm{~d}$ & $4623 \mathrm{c}$ \\
NP & $7.39 \mathrm{bc}$ & $6.50 \mathrm{~b}$ & $5387 \mathrm{~b}$ \\
BHA + NP & $9.15 \mathrm{a}$ & $6.23 \mathrm{c}$ & $6241 \mathrm{a}$ \\
AHA + NP & $8.61 \mathrm{a}$ & $6.21 \mathrm{c}$ & $6243 \mathrm{a}$ \\
MHA + NP & $8.46 \mathrm{ab}$ & $6.70 \mathrm{a}$ & $6147 \mathrm{a}$ \\
\hline
\end{tabular}

"-N" represents only phosphorus fertilizer, no nitrogen fertilizer, "-P" represents only nitrogen fertilizer, no phosphorus fertilizer, "NP" represents nitrogen and phosphate fertilizer, "BHA + NP" represents biochemical humic acid combined with nitrogen and phosphate fertilizer, "AHA + NP" represents ammoniated humic acid combined with nitrogen and phosphorus fertilizer), and "MHA + NP" represents microbial activated humic acid combined with nitrogen and phosphate fertilizer. Different lowercase letters represent significant differences among treatments in the same soil layer $(\mathrm{P}<0.05)$

Table 6. Effects of humic acid combined with fertilizer on cotton nutrient utilization

\begin{tabular}{|c|c|c|c|c|c|c|}
\hline \multirow{2}{*}{ Treatment } & \multicolumn{2}{|c|}{$\begin{array}{l}\text { Nutrient apparent use } \\
\text { efficiency }(\%)\end{array}$} & \multicolumn{2}{|c|}{$\begin{array}{c}\text { Agronomic efficiency of } \\
\text { fertilizer }\left(\mathrm{kg} \mathrm{kg}^{-1}\right)\end{array}$} & \multicolumn{2}{|c|}{$\begin{array}{c}\text { Partial fertilizer productivity } \\
\left(\mathrm{kg} \mathrm{kg}^{-1}\right)\end{array}$} \\
\hline & $\mathbf{N}$ & $\mathbf{P}$ & $\mathbf{N}$ & $\mathbf{P}$ & $\mathbf{N}$ & $\mathbf{P}$ \\
\hline NP & $13.8 \mathrm{c}$ & $11.0 \mathrm{c}$ & $8.1 \mathrm{c}$ & $12.7 \mathrm{c}$ & $38.3 b$ & $83.2 b$ \\
\hline $\mathrm{BHA}+\mathrm{NP}$ & $19.6 b$ & $16.8 \mathrm{~b}$ & $12.3 \mathrm{a}$ & $21.8 \mathrm{a}$ & $44.2 \mathrm{a}$ & $96.5 a$ \\
\hline $\mathrm{AHA}+\mathrm{NP}$ & $28.4 \mathrm{a}$ & $23.4 \mathrm{a}$ & $11.2 \mathrm{ab}$ & $19.8 \mathrm{a}$ & $44.3 \mathrm{a}$ & $96.3 \mathrm{a}$ \\
\hline $\mathrm{MHA}+\mathrm{NP}$ & $20.8 b$ & $21.7 \mathrm{a}$ & $10.5 b$ & $18.3 b$ & $43.5 \mathrm{a}$ & $94.8 \mathrm{a}$ \\
\hline
\end{tabular}

"NP" represents nitrogen and phosphate fertilizer, "BHA + NP" represents biochemical humic acid combined with nitrogen and phosphate fertilizer, "AHA + NP" represents ammoniated humic acid combined with nitrogen and phosphorus fertilizer), and "MHA + NP" represents microbial activated humic acid combined with nitrogen and phosphate fertilizer. Different lowercase letters represent significant differences among treatments in the same soil layer $(P<0.05)$

\section{Discussion}

\section{The combination of humic acid and fertilizer can improve soil physicochemical properties}

According to some analyses, because humic acid is an organic acid, it can combine with cations in the soil to form humate, and then form a buffer system of mutual transformation between humic acid and humate, so it can play a role in regulating soil pH (Boguta et al., 2019). However, in our study, the effect of the three humic acid 
materials on soil $\mathrm{pH}$ was not significant (Fig. 1), which may be related to the high $\mathrm{pH}$ value and of the short period of humic acid materials in this test, or the application of humic acid materials may increase the buffer strength of the soil (Zeng et al., 2013).

Our results showed that the application of the three humic acid materials had a significant reduction in soil EC value, water-soluble $\mathrm{Na}^{+}$and $\mathrm{K}^{+}$content, and SAR (Fig. 2; Table 2), which were similar to the research results of Wang et al. (2016). The reason is that humic acid is a kind of colloid with negative electricity, which can absorb the univalent cation, promote the formation of soil aggregates and increase the permeability of the soil, and accelerating the leaching of salt and alkali on the surface of the soil (Zhao et al., 2017). It is also possible that the hydroxyl and carboxyl functional groups of humic acid condense with calcium ions in the soil, forming soil aggregates through the physiological action of crop roots, thus improving the soil structure and facilitating the leaching of salts (Yonebayashi and Hattori, 1988). In this study, in the 0$40 \mathrm{~cm}$ soil layer, the EC value treated with BHA was lower than that of AHA and MHA (Fig. 2), which may be related to the fact that BHA is biochemical humic acid, with more active groups and large exchange capacity of salt ions (Zhang and Zhang, 2014). There were no significant differences among the three humic acid materials in the influence of soil water-soluble $\mathrm{Na}^{+}$and $\mathrm{K}^{+}$content and SAR (Table 2). Compared with $\mathrm{NP}$, the contents of water-soluble $\mathrm{Ca}^{2+}$ and $\mathrm{Mg}^{2+}$ in soil treated with three humic acids were not significantly different, but the contents of water-soluble $\mathrm{Ca}^{2+}$ and $\mathrm{Mg}^{2+}$ in 0 $10 \mathrm{~cm}$ soil layer treated with MHA was significantly higher than that of BHA and AHA (Table 2), and the reasons remain to be further analyzed.

Through the analysis of the differences of the nitrogen content of various forms in the soil, it was found that the content of $\mathrm{NO}_{3}{ }^{-} \mathrm{N}$ in the soil layer $0-40 \mathrm{~cm}$ after humic acid application significantly decreased, while the content of $\mathrm{NH}_{4}{ }^{+}-\mathrm{N}$ and $\mathrm{SON}$ increased (Table 3). The content of TSN increased in $0-10 \mathrm{~cm}$ soil layer with the humic acid application, but it was lower in the soil layer below $10 \mathrm{~cm}$ than that in the control, which was similar to the results of Tan et al. (1972). The influence of humic acid on the form of soil nitrogen may be related to the that the carboxyl group and phenolic hydroxyl group of humic acid can react with the amide group of urea to form humic acid urea complex, and the carboxyl group of humic acid can combine with ammonium to form ammonium humate (Aquino et al., 2011). It is also possible that humic acid can stimulate root growth and promote the uptake of nitrogen by crops (Jindo et al., 2012). In farmland, soluble organic nitrogen mainly comes from the humification of organic matter and microbial decomposition (Zang et al., 2000). Humic acid, as an organic modifier, increases the content of soil organic matter on the one hand (JiménezGonzález et al., 2019), and on the other hand provides more carbon sources for microorganisms, which has a stimulating effect on the decomposition of soil organic matter (Singh et al., 2019), which may also be the reason why humic acid application improves the content of soil soluble organic nitrogen (Xing et al., 2010). Among the three humic acid materials, mineral humic acid had the best effect in reducing the content of $\mathrm{NO}_{3}{ }^{-}-\mathrm{N}$ in soil and increasing the content of $\mathrm{NH}_{4}{ }^{+}-\mathrm{N}$. The effect of BHA and MHA on increasing the content of SON was as deep as $40 \mathrm{~cm}$ soil layer in the application season, while the effect of AHA was only significant in 0-10 cm soil layer. There was no significant difference in the TSN content between BHA and NP in 0$40 \mathrm{~cm}$ soil layer, while the TSN content of AHA and MHA in $0-10 \mathrm{~cm}$ soil layer was significantly higher than that of NP, and that in soil layer below $10 \mathrm{~cm}$ is significantly lower than that in NP (Table 3). The results of the significant increase of TSN content 
of mineral source humic acid in $0-10 \mathrm{~cm}$ soil layer were mainly due to the increase of SON content, while the results of the decrease of TSN in $10-20 \mathrm{~cm}$ and $20-40 \mathrm{~cm}$ soil layer were mainly due to the decrease of $\mathrm{NO}_{3}{ }^{-}-\mathrm{N}$ content. The decrease of $\mathrm{NO}_{3}{ }^{-}-\mathrm{N}$ content is beneficial to the reduction of nitrogen leaching loss and the alleviation of groundwater pollution. The increase of $\mathrm{NH}_{4}{ }^{+}-\mathrm{N}$ and $\mathrm{SON}$ content is beneficial to the fixation of soil nitrogen and has a positive effect on the satisfaction of nitrogen nutrition demand in the later growth stage of cotton. It can be seen that the effect of mineral humic acid on nitrogenous fertilizer is better than that of biochemical humic acid.

Relevant research results showed that after humic acid was applied into the soil, it could combine with $\mathrm{Ca}^{2+}$ in the soil and reduce Ca-P precipitation (Perassi and Borgnino, 2014). The hydroxyl functional group of humic acid can react with phosphoric acid to form water-soluble phosphorus humic acid and humic acid ammonium phosphorus (Cimrin and Yilmaz, 2005). Wang et al. (2020) found that the available phosphorus content in the soil treated with additional humic acid was significantly higher than that treated with phosphate fertilizer alone, and the fixation rate of soil to phosphorus was reduced. This study also drew a similar conclusion that humic acid could improve the content of soil available phosphorus to a certain extent, and the effect of MHA was the most significant (Table 4).

The three humic acid materials all showed a certain effect on the improvement of saline-alkali soil, but the influence degree of different materials on the physical and chemical properties of soil was different. The reason for the difference is that humic acid is a kind of mixture composed of various compounds with different molecular weights. Humic acid raw materials from different origins and different sources have different processing and activation technologies, and their active humic acid content, functional group type, quantity, and activity are different (Wang et al., 2016). In addition, it also may be that the contents of organic matter, total nitrogen, and total potassium of the three humic acid materials vary greatly (Table 1), even though the availability of the materials as the total nutrients is limited in season, which led to the different effects of the materials on the physical and chemical properties of saline and alkaline land.

\section{The combination of humic acid and fertilizer promote the growth and development of plants, and increase the yield and nutrient absorption and utilization of cotton}

Humic acid can obviously promote the absorption of $\mathrm{N}, \mathrm{P}$, and $\mathrm{K}$ nutrients in plants, effectively improve the agronomic traits of crops, increase the yield of crops, and promote the absorption and utilization of nutrients in crop plants (Fawzy et al., 2010). In our study, the synergistic effect of humic acid was mainly reflected in the significant improvement of chlorophyll content, biomass, yield, apparent fertilizer utilization rate, and agronomic efficiency of cotton. The increase of chlorophyll content may be related to the application of humic acid promoting the absorption of $\mathrm{Mg}^{2+}$ or $\mathrm{Fe}^{2+}$ (Mackowiak et al., 2001). This study showed that different humic acid materials could improve cotton biomass in different degrees under the same nutrient input, and AHA treatment reached a significant level, which was similar to the results (Atiyeh et al., 2002). This may be because mineral humic acid can promote the activities of polyphenol oxidase, catalase, and invertase, etc. The enhancement of the enzyme activity speeds up the metabolic process of cotton, thus promoting the growth of cotton (Arancon et al., 2006). Compared with NP, the yield of cotton treated with additional humic acid increased by $14.1-15.9 \%$, but there was no significant difference between the three humic acid 
materials on the yield (Table 5). Compared with NP, the utilization rate of nitrogen and phosphorus fertilizer in cotton treated with humic acid increased by $42.0-104.2 \%$ and $11.7-55.0 \%$, respectively, and the AHA treatment had the best effect of increasing the utilization rate of nitrogen and phosphorus fertilizer (Table 6). The combination of humic acid and fertilizer can improve yield and nutrient utilization. On the one hand, it is related to the improvement of physical and chemical properties of saline-alkali soil by humic acid, which reduces the harm of saline-alkali to crops and creates a more favorable soil environment for the growth of cotton. In addition, humic acid has the function of activating nitrogen and phosphorus and improves the availability of nitrogen and phosphorus (Allison, 2006; Khaled and Fawy, 2011). On the other hand, it may be related to the fact that humic acid can stimulate root growth and development of crops, increase root length, root mass, and root activity, and thus contribute to the improvement of root absorption capacity (Hatami et al., 2018; Jindo et al., 2012).

\section{Conclusions}

The effect of a combination of humic acid and fertilizer on saline-alkali land improvement is remarkable. Compared with single fertilizer application, electrical conductivity (EC), water soluble $\mathrm{Na}^{+}$and $\mathrm{K}^{+}$, content and SAR of soil treated with additional humic acid decreased significantly. BHA had the best effect on reducing soil $\mathrm{EC}$, but there was no significant difference among the three humic acid materials in reducing the content of $\mathrm{Na}^{+}$and $\mathrm{K}^{+}$and the effect of SAR. The content of soluble organic nitrogen in soil could be improved to some extent by applying humic acid, and the BHA and MHA acted at a depth of $40 \mathrm{~cm}$. The content of available phosphorus in soil could be significantly increased by $18.7-101.5 \%$ by applying humic acid, among which the MHA effect was the best. The effect of three humic acid materials on the growth and yield of cotton was not obvious but compared with the control treatment with the same nutrient fertilizer. The chlorophyll content and biomass of flowering and boll stage functional leaves of cotton with additional humic acid were significantly increased, the cotton yield increased by $15 \%$, and cotton nitrogen and phosphorus fertilizer use efficiency increased by $42.0-105.8 \%$ and $52.7-112.7 \%$, respectively. To sum up, the application of different humic acid materials on saline-alkali land has different effects on soil physical and chemical properties, but the overall effect of improving saline-alkali land and increasing cotton yield is significant. However, due to the short period of this experiment, the medium and long-term effects of different humic acids on soil physical and chemical properties and crop growth need to be further studied.

Acknowledgements. This work was supported by the Central Public Welfare Scientific Research Basic Scientific Research and Special Funds (HKY-JBYW-2020-13 and HKY-JBYW- 2018-04).

\section{REFERENCES}

[1] Abe, T., Kobayashi, S., Kobayashi, M. (2011): Aggregation of colloidal silica particles in the presence of fulvic acid, humic acid, or alginate: effects of ionic composition. Colloids and Surfaces A: Physicochemical and Engineering Aspects 379: 21-26.

[2] Allison, S. D. (2006): Soil minerals and humic acids alter enzyme stability: implications for ecosystem processes. - Biogeochemistry 81: 361-373. 
[3] Aquino, A. J., Tunega, D., Pašalić, H., Schaumann, G. E., Haberhauer, G., Gerzabek, M. H., Lischka, H. (2011): Study of solvent effect on the stability of water bridge-linked carboxyl groups in humic acid models. - Geoderma 169: 20-26.

[4] Arancon, N. Q., Edwards, C. A., Lee, S., Byrne, R. (2006): Effects of humic acids from vermicomposts on plant growth. - European Journal of Soil Biology 42: S65-S69.

[5] Asli, S., Neumann, P. M. (2010): Rhizosphere humic acid interacts with root cell walls to reduce hydraulic conductivity and plant development. - Plant and Soil 336: 313-322.

[6] Atiyeh, R. M., Lee, S., Edwards, C. A., Arancon, N. Q., Metzger, J. D. (2002): The influence of humic acids derived from earthworm-processed organic wastes on plant growth. - Bioresource technology 84(1): 7-14.

[7] Boguta, P., D’Orazio, V., Senesi, N., Sokołowska, Z., Szewczuk-Karpisz, K. (2019): Insight into the interaction mechanism of iron ions with soil humic acids. The effect of the $\mathrm{pH}$ and chemical properties of humic acids. - Journal of Environmental Management 245: 367-374.

[8] Ciarkowska, K., Sołek-Podwika, K., Filipek-Mazur, B., Tabak, M. (2017): Comparative effects of lignite-derived humic acids and FYM on soil properties and vegetable yield. Geoderma 303: 85-92.

[9] Cimrin, K. M., Yilmaz, I. (2005): Humic acid applications to lettuce do not improve yield but do improve phosphorus availability. - Acta Agriculturae Scandinavica, Section BSoil \& Plant Science 55(1): 58-63.

[10] Dehghani, M. H., Zarei, A., Mesdaghinia, A., et al. (2018): Production and application of a treated bentonite-chitosan composite for the efficient removal of humic acid from aqueous solution. - Chemical Engineering Research and Design 140: 102-115.

[11] Erhayem, M., Sohn, M. (2014): Effect of humic acid source on humic acid adsorption onto titanium dioxide nanoparticles. - Science of the Total Environment 470: 92-98.

[12] Fan, H. M., Wang, X. W., Sun, X., Li, Y. Y., Sun, X. Z., Zheng, C. S. (2014): Effects of humic acid derived from sediments on growth, photosynthesis and chloroplast ultrastructure in chrysanthemum. - Scientia Horticulturae 177: 118-123.

[13] Fawzy, Z., Abd El-Baky, M., Mahmoud, R. (2010): Response of snap bean plants to mineral fertilizers and humic acid application. - Research Journal of Agriculture and Biological Sciences 6: 169-175.

[14] Hatami, E., Shokouhian, A. A., Ghanbari, A. R., Naseri, L. A. (2018): Alleviating salt stress in almond rootstocks using of humic acid. - Scientia Horticulturae 237: 296-302.

[15] He, Z., Olk, D. C., Cade-Menun, B. J. (2011): Forms and lability of phosphorus in humic acid fractions of hord silt loam soil. - Soil Science Society of America Journal 75: 17121722.

[16] He, K., He, G., Wang, C. P., Zhang, H. P., Xu, Y., Wang, S. M., Kong, Y. Z., Zhou, G. K., Hu, R. B. (2020): Biochar amendment ameliorates soil properties and promotes Miscanthus growth in a coastal saline-alkali soil. - Applied Soil Ecology 155: 103674.

[17] Ifansyah, H. (2014): Soil pH and solubility of aluminum, iron, and phosphorus in ultisols: the roles of humic acid. - Jurnal Tanah Tropika 18: 203-208.

[18] Jiménez-González, M. A., Álvarez, A. M., Carral, P., Almendros, G. (2019): Chemometric assessment of soil organic matter storage and quality from humic acid infrared spectra. - Science of The Total Environment 685: 1160-1168.

[19] Jindo, K., Martim, S. A., Navarro, E. C., Pérez-Alfocea, F., Hernandez, T., Garcia, C., Aguiar, N. O., Canellas, L. P. (2012): Root growth promotion by humic acids from composted and non-composted urban organic wastes. - Plant and Soil 353: 209-220.

[20] Khaled, H., Fawy, H. A. (2011): Effect of different levels of humic acids on the nutrient content, plant growth, and soil properties under conditions of salinity. - Soil and Water Research 6: 21-29.

[21] Li, Y., Fang, F., Wei, J. L., Wu, X. B., Cui, R. Z., Li, G. S., Zheng, F. L., Tan, D. S. (2019): Humic acid fertilizer improved soil properties and soil microbial diversity of continuous cropping peanut: a three-year experiment. - Scientific Reports 9(1): 12014. 
[22] Li, N., Lin, H. X., Wang, T. X., Li, Y., Liu, Y., Chen, X. G., Hu, X. T. (2020): Impact of climate change on cotton growth and yields in Xinjiang, China. - Field Crops Research 247: 107590.

[23] Liang, J. P., Shi, W. J., He, Z. J., Pang, L. N., Zhang, Y. C. (2019): Effects of poly- $\gamma-$ glutamic acid on water use efficiency, cotton yield, and fiber quality in the sandy soil of southern Xinjiang, China. - Agricultural Water Management 218: 48-59.

[24] Liu, M. L., Wang, C., Wang, F. Y., Xie, Y. J. (2019): Maize (Zea mays) growth and nutrient uptake following integrated improvement of vermicompost and humic acid fertilizer on coastal saline soil. - Applied Soil Ecology 142: 147-154.

[25] Mackowiak, C. L., Grossl, P. R., Bugbee, B. G. (2001): Beneficial effects of humic acid on micronutrient availability to wheat. - Soil Science Society of America Journal 65: 1744-1750.

[26] Mahdy, A. M. (2011): Soil properties and wheat growth and nutrients as affected by compost amendment under saline water irrigation. - Pedosphere 21(6): 773-781.

[27] Margot, A., Flaschel, E., Renken, A. (1994): Continuous monitoring of enzymatic whey protein hydrolysis. Correlation of base consumption with soluble nitrogen content. Process Biochemistry 29(4): 257-262.

[28] Perassi, I., Borgnino, L. (2014): Adsorption and surface precipitation of phosphate onto $\mathrm{CaCO}_{3}$-montmorillonite: effect of $\mathrm{pH}$, ionic strength and competition with humic acid. Geoderma 232: 600-608.

[29] Selladurai, R., Purakayastha, T. J. (2016): Effect of humic acid multinutrient fertilizers on yield and nutrient use efficiency of potato. - Journal of Plant Nutrition 39(7): 949-956.

[30] Sharpley, A. N. (1991): Effect of soil $\mathrm{pH}$ on cation and anion solubility. Communications in Soil Science and Plant Analysis 22(9): 827-841.

[31] Singh, S., Kumar, V., Singh, S., Singh, J. (2019): Influence of humic acid, iron and copper on microbial degradation of fungicide Carbendazim. - Biocatalysis and Agricultural Biotechnology 20: 101196.

[32] Sudiarto, S. I. A., Renggaman, A., Choi, H. L. (2019): Floating aquatic plants for total nitrogen and phosphorus removal from treated swine wastewater and their biomass characteristics. - Journal of Environmental Management 231: 763-769.

[33] Tan, K. H., Beaty, E. R., McCreery, R. A., Powell, J. D. (1972): Humic-Fulvic acid content in soils as related to ley clipping management and fertilization. - Soil Science Society of America Journal 36(4): 565-567.

[34] Tan, S., Wang, Q. J., Zhang, J. H., Chen, Y., Shan, Y. Y., Xu, D. (2018): Performance of AquaCrop model for cotton growth simulation under film-mulched drip irrigation in southern Xinjiang, China. - Agricultural Water Management 196: 99-113.

[35] Türkmen, Ö., Dursun, A., Turan, M., et al. (2004): Calcium and humic acid affect seed germination, growth, and nutrient content of tomato (Lycopersicon esculentum L.) seedlings under saline soil conditions. - Acta Agriculturae Scandinavica, Section B - Soil \& Plant Science 53(3): 168-174.

[36] Wang, F. Y., Wang, C., Liu, Q. Q., Jin, S. J., Xie, J. Y. (2016): Improve effect of humic acid, earthworm protein fertilizer and vermicompost on coastal saline soils. - Journal of China Agricultural University 20(5): 89-94. (in Chinese with English abstract)

[37] Wang, Q. Z., Wang, Y., Sun, Z. M., Liu, J., Niu, S. B., Xue, C., Ma, W. Q. (2019): Amelioration effect of humic acid on saline-alkali soil. - Chinese Journal of Applied Ecology 30(4): 1227-1234 (in Chinese with English abstract).

[38] Wang, M., Liu, S., Zhang, S., Zhang, Q., Mu, K., Chen, Q. (2020): Effect of potassium humate and phosphate fertilizer application method on soil phosphate mobility. - Journal of Agricultural Resources and Environment 37(2): 209-215.

[39] Xiao, Y. S., Peng, F. T., Zhang, Y. F., Wang, J., Zhuge, Y. P., Zhang, S. S., Gao, H. F. (2019): Effect of bag-controlled release fertilizer on nitrogen loss, greenhouse gas emissions, and nitrogen applied amount in peach production. - Journal of Cleaner Production 234: 258-274. 
[40] Xie, W. Q., Gong, Y. X., Yu, K. X. (2019): An efficient headspace gas chromatographic technique for determining humic acid content in fertilizer. - Journal of Chromatography A 1596: 194-198.

[41] Xing, S. H., Chen, C. R., Zhou, B. Q., Zhang, H., Nang, Z. M., Xu, Z. H. (2010): Soil soluble organic nitrogen and active microbial characteristics under adjacent coniferous and broadleaf plantation forests. - Journal of Soils and Sediments 10(4): 748-757.

[42] Yang, Y. L., Chen, M. Z., Tian, J. S., Xiao, F., Xu, S. Z., Zuo, W. Q., Zhang, W. F. (2019): Improved photosynthetic capacity during the mid- and late reproductive stages contributed to increased cotton yield across four breeding eras in Xinjiang, China. - Field Crops Research 240: 177-184.

[43] Yonebayashi, K., Hattori, T. (1988): Chemical and biological studies on environmental humic acids. - Soil Science and Plant Nutrition 34(4): 571-584.

[44] Zang, X., van Heemst, J. D., Dria, K. J., Hatcher, P. G. (2000): Encapsulation of protein in humic acid from a histosol as an explanation for the occurrence of organic nitrogen in soil and sediment. - Organic Geochemistry 31(7-8): 679-695.

[45] Zeng, W. A., Zeng, M., Zhou, H., Lei, M., Hu, L. Q. (2013): Improvement of alkaline tobacco field soil by combined application of humic acid and ferric sulfate. - Journal of Soil and Water Conservation 27(03): 170-173 (in Chinese with English abstract).

[46] Zhang, Y. P., Zhang, X. Z. (2014): Extraction and characterization of biotechnology humic acid of fermented furfural residue. - Journal of Anhui Agricultural Science 42: 9752-9754 (in Chinese with English abstract).

[47] Zhang, M., Xiao, H. J., Zhao, H., An, J. Y., Qin, S., Gou, J. L., Hu, G. (2016): Responses of dry matter, nitrogen accumulation and distribution and nitrogen utilization of pepper to new-type fertilizers in Guizhou yellow soil. - Chinese Journal of Applied Ecology 27(9): 2983-2990 (in Chinese with English abstract).

[48] Zhang, Q., Li, Y., Xing, J. J., Brookes, P. C., Xu, J. M. (2019a): Soil available phosphorus content drives the spatial distribution of archaeal communities along elevation in acidic terrace paddy soils. - Science of The Total Environment 658: 723-731.

[49] Zhang, S. Q., Liang, Y., Li, W., Lin, Z. A., Li, Y. T., Hu, S. W. (2019b): Effects of urea enhanced with different weathered coal-derived humic acid components on maize yield and fate of fertilizer nitrogen. - Journal of Integrative Agriculture 18(3): 656-666.

[50] Zhao, S. X., Chen, Z. L., Shen, J. M., Kang, J., Shen, Y. Q. (2017): Leaching mechanisms of constituents from fly ash under the influence of humic acid. - Journal of Hazardous Materials 321: 647-660. 